\title{
The Role and Position of Bundo Kanduang In Local Color of Minangkabau Contemporary Novels
}

\author{
Irfani Basri, Ellya Ratna, and Zulfikarni \\ Faculty of Languages and Arts \\ Universitas Negeri Padang
}

\begin{abstract}
This research was generally aimed to explain about the role and the position of Bundo Kanduang in local color novels Minangkabau written in the New Era. Specifically, it focused on creating a systematic, factual, and accurate picture or painting of the facts, traits and relationships among the phenomena under investigation. This qualitative research has data that decomposes in the form of words or images, not in the form of numbers. This study applied content analysis approach (content analysis) because it intends to dig the contents and messages contained in data or research data sources. Based on the research found that women as Bundo Kanduang in the people on the novels Minangkabau background in the New Era looks more freely in running its role. A woman can take her own decisions in running her life, and even has actively participated in the institution of women's empowerment. They are more able to choose the preferred spouse. In some novels they even dare to reject the rules that they think harm the people. In addition, some novels revealed the existence of women through working, not limited to taking care of the household, but can be involved in the community.
\end{abstract}

Keywords--Role, Position, Bundo Kanduang, Novel, New Era

\section{INTRODUCTION}

Minangkabau for Minangkabau people become as a view of life that based on the mind so that to get a prime position in the association of religious life and religion. Simply can be understood that adat (culture) is everything a means of regulating life and community life in order to be orderly and serene without neglecting the religious, legal, and social aspects. In other words, Minangkabau culture is used as an unwritten law to be followed by every member of the community.

Minangkabau's culture prevailing in the midst of society until now also peeled in the literary (novel). Novels as literary works provide an opportunity for authors to convey the issues observed, discovered, and perceived. This is due to the existence of its author as a social being. Esten (1984, p. 12) explained that the existence of an Indonesian literary is an artist of two worlds: the world of regional culture and the new world of Indonesia. His novel will never be separated from the influence of the cultural value system of the region where the writer came from.

It is not surprising that in the realm of Indonesian literature sprang writers from ethnic Minangkabau who talked about the issue of the Minangkabau, even though they obtained education outside Minangkabau's area. Even Minangkabau's people who are educated in these Minangkabau outer cultural centers are bringing progress and creative reflection. One of the creative reflections is embodied in a novel literary work. Among the Indonesian writers who made Minangkabau's cultural treasures as the source of creation were Marah Rusli (Siti Nurbaya), Sutan Sati (Sengsara Membawa Nikmat), Hamka (Tenggelamnya Kapal Van der Wijck), A.A. Navis (Kemarau) and Wisran Hadi (Orang-orang Blanti), as well as many other authors who gave birth to Minangkabau's culture.

Since the 1920s, literary works (the novel) that examines the problems of the Minangkabau's community as a matrilineal society, also talk about women as people who are reckoned in Minangkabau 's culture. Siti Nurbaya and Salah Asuhan are two novels with big names. The two novels talk about the controversial Minangkabau's ethnic, causing debate. By reading the novel, there will be a change of mindset and cultural orientation of the reader in a more open direction. This proves that the novel is not only based on the imagination of the author, but also based on the reality that developed in society.

The number of literary works of Minangkabau's culture that have been published and get various awards. Starting from that the authors wanted to examine the role and the position of women as the figure of Bundo Kandung in the novels. The selection of the novels was based on the cultural issues raised by the author. The analysis of local Minangkabau novels written in the New Era aims to find the role and the position of women as the figure of Bundo Kanduang. 


\section{Culture in Literature}

Culture can be seen from a wide range and narrow coverage. Koentjaraningrat $(1974$, p. 1) explains that in the narrow sense of culture is a mind, work, and the work of human who fulfills the desire for beauty. This sense is said to be narrow because beauty is just one aspect of culture. On the other hand, in a broad sense, culture is the total of the thoughts, works, and works of human that are not rooted in his instincts. Therefore, culture can be triggered by humans through the learning process.

Louis (1970, p. 60) formulated five characteristics of culture. First, culture is a way of life. Second, culture is the whole of the plan or the design of life. Third, the functional culture is organized in a system. Fourth, culture is gained through learning. Fifth, culture is the way of life of a social group or group, not an individual or individual way of life.

Maran (2000, p. 27) explains that culture is a unity composed of different parts. The parts that make up the culture are integrated and interconnected. Changes to one part of the system will change the relationship between the other parts and will affect the whole system. Values are an idea of something good, to be expected. They are the basis for the formation of social norms, the rules of how one should behave. These values and norms differ from one culture to another.

Cultural analysis is essentially an analysis of the forms of values held and used by a particular group of people. Literature as a cultural product cannot stand alone. Among these cultures there is an interrelated relationship (Yusriwal, 2004, p. 171). Minangkabau 's culture in a novel set in Minangkabau. The intersection between the literary and novel works of culture prevailing in the Minangkabau's society will be seen in the literary work.

Novels created by authors derive from the realities that exist in the midst of people's lives. In addition to entertainment, a novel is expected to provide valuable values to its readers especially those dealing with life issues. Thus, the novel as a literary product is expected to serve as a mirror in behaving and behaving for the community. If the function has been achieved, by itself the work of literature will be a work that is useful and good value for the reader.

\section{The form of Culture at Bundo Kanduang 's Position}

Based on Minangkabau's custom law, Bundo Kanduang is a vocation of women according to Minangkabau's custom. The meaning of bundo is the mother, the ingredients are true. So, Bundo Kanduang is a true mother who has the character of motherhood and leadership. Gouzali (2004, p. 60) states that Bundo Kanduang scientifically is the mother who gave birth or biological parents.

Furthermore, Idrus (2004, p. 69-70) argues that the Bundo Kanduang as the mother to draw the ropes of the Minangkabau's community are collected in a phrase that; Bundo Kanduang, limpapeh rumah nan gadang, umbun puruak pegangan kunci, umbun puruak aluang buniang, pusek jalo kumpulan tali, sumarak di dalam kampuang, hiasan dalam nagari, nan gadang basa batuah, kok hiduik tampek banasa, kok mati tampek baniaik, kaundang-undang ka madinah, kapayuang panji ka sarugo. (female or biological mother, butterfly in the house of the people, the key holder, the main center of survival in the household, the embellishment in society, the place of problem solving, the bearer to the path of truth, the role model to eternal life in heaven.)

Based on the statement can be concluded, that a Bundo Kanduang has double duty. First, Bundo Kanduang as the center of all power within the people. Second, a Bundo Kanduang must be able to be a good wife for her husband. Third, Bundo Kanduang is the person who will manage all the needs of the household and be an example for members of her people. Fourth, a Bundo Kanduang is a person who can socialize in the community where her lived. Fifth, Bundo Kanduang is a symbol of pride and glory that mediates the descendants raised and respected so that she is required to have good personality. Sixth, a Bundo Kanduang is required to direct the members of the people towards the happiness of the world and the hereafter.

Furthermore Idrus (2004, p. 77-80) states that a Bundo Kanduang must have the qualities of leadership and the true mother as follows :

1) Right

Bundo Kanduang has true properties. That is, true in speech is also true in deeds and behavior. It also always educates people in their environment with the traits of truth and upholds the truth.

2) Honest, Born and Inner Believed.

Bundo Kanduang has a honest nature. That is, honest in words and deeds and always educate the environment, with examples and actions that are honest and good. Bundo Kanduang will reject all forms of action that are contrary to honesty such as stealing, cheating, and other bad traits.

3) Ingenious

Bundo Kanduang must be ingenious. Ingenious means to have the nature of know and clever. Know, that means knowing anything harmful and beneficial. Know, meaning knowledgeable knowledge in the household and the environment, 
knowledgeable about education and experts in the field of femininity and knowledge in the field of customs and religion and the state. Clever, meaning always put everything in place and good at hanging out with everyone.

4) Clever Speaking

Bundo Kanduang must be good at talking. That is, Bundo Kanduang must be fluent in words because Bundo Kanduang `s function as educators, both at home and in the community.

5) Shy

Bundo Kanduang must has shy nature. That is, the shy nature of women will be regarded as a virtuous woman as the saying goes; rarak kalikia dek binal / tumbuah sarumpun jo sikasek / kok is hilang raso jo malu / bak kayu lungga pangabek. The meaning is, if a Bundo Kanduang has not the shy nature, the direction of her life will be messy and cannot serve as role models for members of her people.

\section{METHODS}

The object of this research was all the events experienced by story characters in local color Minangkabau's novels written during the New Era. The data of this research are words, phrases, clauses, and sentences that state the role and the position of the Bundo Kanduang. In addition, research data is also in the form of data generated intuitively by researchers and ditriangulasi to the experts of the field of literature.

\section{THE ROLE AND THE POSITION OF WOMEN AS BUNDO KANCUSSION}

The position of women in Minangkabau as Bundo Kanduang 's figure in the novel colors of local Minangkabau in the New Era will be described in the following explanations.

1. The role and the position of women as Bundo Kanduang in novel Tambo: "Sebuah Pertemuan" by Gus Tf. Sakai

Bundo Kanduang is a call to the women according to Minangkabau's culture (adat). Bundo means mom it means true. So Bundo Kanduang is a true mother who has the character of motherhood and leadership. Under Minangkabau's culture law, Gouzali (2004: 60) suggests that Bundo Kanduang is the mother who gave birth or biological parents. As a parent, Bundo Kanduang plays a mother who conceives, gives birth, breastfeeds, raises, and educates her children until she /he becomes a useful human being. To be more clearly can be seen through some of the following explanations.

a. As a Wife

In addition, a Bundo Kanduang in Minangkabau also plays a role in the family of her husband as the following state.

For a woman, or a wife, marriage is not only to be a wife and to bear children from her husband but also to be a representative in her husbands (Sakai, 2000, p. 53-54).

However, on the other hand, there is an abusive treatment of women by making them a victim of male power. It can be seen in the following state.

Each looked bundo, every look at my sister, Siti Jamilah, every look at women, women anywhere in any part of the world, I always see the power to ravage them. In the area of conquest incarnated screams, in victory areas incarnate entertainment. No more than objects, the legitimacy of what men call virile (Sakai, 2000, p. 39)

Based on the statemen, it is seen through the figure of Rido, when he views his mother and sister who have done many things for his family and his people, but still gets the arbitrary treatment of a power. Women do not get the place they should be in front of men. They are not just goods that can be made a bet, entertainment, and victims of power struggles. In that case, the figure of Rido who transformed into Sutan Balun back into the past and wants to put women the same as men. This is as illustrated in the following statement.

But what I want most is something that has been felt since the point of marriage, the position of women that is placed in a place that is not less important than men. Even as an owner, women can be very decisive. (Sakai, 2000, p. 56)

Through the statement, it appears that the desire of Sutan Balun as a man and a leader to place women in Minangkabau's culture (adat) as a person to be reckoned with. Even more than that, that is as the owner. As the owner, women will not be wasted. She has a strong position in determining decisions so that women are not treated haphazardly, either by power or by men.

b. As Mother 
In the novel "Tambo": A Meeting (Sebuah Pertemuan), the author describes the role and position of the bundo kanduang as a mother figure. This can be seen from the picture of "mother" from the character Rido. For more details, the role and the position of the bundo kanduang can be seen in the following statement :

I love mom and mother loves me. My mother is a mighty .... (Sakai, 2000, p. 6)

How are you, baby? Mother is in the village always be in good health and happy. So it should be with you here. Always mother praying, hopefully you are overwhelmed by God's energy and intelligence (Sakai, 2000, p. 8)

Through the statement that has been presented that a mother gives love and affection wholeheartedly to her child. Even though her child is an adult, she will continue to pray for her son to always be in the protection of Almighty God and hope that her son will gain strength and goodness. A mother who keeps herself alright and always happy to keep her child from worrying. It was seen from the mother's statement to her son Rido that she was in good condition and happy in the letter she sent. Though not necessarily the situation as he delivered.

c. As a Family Member

Besides being a mother, bundo kanduang is also a brave woman to defend herself, her family, and her people. Sometimes a candidate bundo must also be able to be a single parent. It can also be seen in the following statement

... mother is the only woman in our village who dared to bring a message from someone to someone else during PRRI. Mother was also the only widow in our village who did not need another man after her husband died, when at that time she was so young, beautiful and radiant (Sakai, 2000, p. 21)

The next statement

And from my mother, Bundo, I found a hardness wrapped by tenderness. Really she was the most amazing woman ever. History and life have forged her in such a way, making her different, more than any woman. (Sakai, 2000, p. 30)

Based on the statement, it can be understood that a bundo other than as a mother, she can also act as a hero for her people. To be a hero in the defense of her people, demanded courage and intelligence. Even in the novel is also described that women as mothers can also maintain survival without having to depend absolutely to the husband. That is, she can be a savior in the family when her husband died or sick. She can be tough to face the problems faced in living life as an independent. Women also accept the problems faced by children and their families, before they tell the men or her uncle to be resolved. This is illustrated in the following statement:

After a wife becomes a mother, her role is to lead in a family that controls everything. It is she who accepts the problems of a child to be delegated to her brother (the uncle) (Sakai, 2000, p. 54)

Thus, in the novel Tambo: Sebuah Pertemuan by Gus Tf Sakai, it is described that women as bundo kanduang has a great responsibility to their family, people and husband. Therefore, women need to get a respectable and calculated place. In Minangkabau's society culture, women are placed as determinants in making decisions, as owners in the matter of property heirloom. They are not a soft object to be sacrificed. They are objects that can be made a bet anywhere.

The position of bundo kanduang in Minangkabau's cultural custom is as a group of interstitial ladies who must maintain themselves and perform their duties according to customary and religious rules. In the novel Tambo, a woman described the author only as a victim of intimidation from the men, either intentionally or unintentionally. The woman who was supposed to participate as a determinant in taking a decision in Minangkabau `s society was just an ideals of the founding leaders of adat it was just an old story that was not realized in real terms. Through the character Ridho described that he saw women treated as weak creatures who cannot do much and accept what has been decided by her people without being able to do much.

\section{The Position of Women as Bundo Kanduang in Novel "Bako" by Darman Moenir}

a. As a Wife

Furthermore, in the novel "Bako", bundo kanduang role played by Ummi figures, so clearly visible. The female characters of the three novels have provided good examples and role models to the children and members of their people. They are not only struggled with domestic affairs, but also defended their families and families. Ummi figures participate in the 
continuity of their brothers 'sons' schools, both materially and inmateri, even mortgaging their fields for the sake of their children's education.

As a wife, Moenir does not explain much about the role of a bundo kanduang as a wife. However, through the character of mother "I" declared that her mother can not be fair, both as a mother and as a wife because of the mental disorders experienced by the character. As seen through the following statement:

In my mind, it is only natural that my mother suffers from psychic pressure ... when she is married and in childhood, she is abandoned by her husband. How much more if she was not in her own village, but living in her mother-in-law's house. (Moenir, 1983, p. 21)

Through the statement is explained that the character of mother "I" because of psychiatric disorders. As a result, as a woman, she can not play the role as a wife and a mother. In that case, the figure of bundo kanduang cannot be found in this character.

\section{b. As Mother}

Darman Moenir in the novel "Bako" further highlight the role of women from the father's family, not from women as biological mother. In the novel is described the condition of the mother of character man experiencing psychiatric disorders. Therefore, the role of women as mothers is taken over by a bako (sister) who is called Ummi and has no children. Nevertheless, women as a biological bundo also visible from the bako attitude in taking care children her brother, can be seen from the following statement

Eventually I begin to understand why I am not raise and educate in the mother's family environment. Rather in the family environment of the father. I do not have time to spend my childhood with my sister more, let alone every day. She lives and raise by others. The other person is my uncle, my mother's sister, whom I have only ever recorded in my life. While I was taken to the bako house. (Moenir, 1983, p. 15-16)

Through the statement, there is the role of bako (father's sister) in taking the role of mother's successor to her brother's children. Through Ummy's character, in Bako's novel, a bundo kanduang's candidate wants to open herself up to be a mother, though not her own child.

\section{c. As a Community Member}

In addition to being a person who take care household and family needs, women in Bako's novel is already there who tasted formal education and engaged in organizational activity, both political and humanity. Thus, the mindset depicted through mother (Ummi) figures is more advanced than the other female roles that only take care of households without prioritizing education and knowledge, as in mother (Ummi) figures presented by the following statement.

Having attended the Madrasah School of God is a rare occurrence of the day. Especially if the school is a woman (Moenir, 1983, p. 30).

Women in my village, to name a few ancient stories, but still often actual, after coming menstruation periods immediately found her husband and they are not surprised if used as a second wife, third, and so on, they are only in the home cooking and giving birth. At the very least, my ummah is not willing to take such ways. She ventured to take a role in a society that men usually do (Moenir 1983, p. 59).

Progress in thinking is also seen when mother (ummi) wants to give heritage treasures owned for the benefit of the school, although not the children of her people or children of her younger brother is good illustrates that the figure of women as bundo kanduang can take care member of her family. Mother's (Ummi) figure has performed her role as a woman in her people, her relatives, and the surrounding community. It can be seen in the following statement.

If there is no mother (ummi), again, it is not impossible that all of her children will be abandoned. Mother (Ummi) hold an important role. It is herself who manages all their needs. Starting from the food until the preparation school. Starting from wiping snot to pull them at night. (Moenir, 1983, p. 88)

By understanding the statement in novel "Bako", it is concluded that the role of women as a figure of bundo kanduang is not just an ordinary or "home" woman. Through mother (ummi) leaders, besides being a mother to her relatives mother 
(ummi) also cares about education, both for herself and her family. In addition, mother (ummi) also participated in the community to fight for women's rights.

\section{The Position of Women as Bundo Kanduang in the Novel "Orang-Orang Blanti" by Wisran Hadi}

In novel Orang Orang Blanti, the role of bundo kanduang is not so visible. Grandmother's character can not defend the heritage (pusako) land from Datuk Tuo's insistence to sell it. Through the case, it appears that the figure of bundo kanduang has no authority in making decisions. As stated by Navis (1986, p. 74) that men in Minangkabau have power and power against the people. This is due to the matrilineal familial system. The lineage is derived from the mother, but there are uncle (mamak) who have power to set division of inheritance or pusako.

\section{a. As Mother}

Thus, it appears that the status of women as bundo kanduang does not work properly. The matrilineal kinship system in Minangkabau 's culture should give women the right to use and enjoy inheritance (pusako) treasures as well as possible. As stated by Idrus (2004: 73) that good inheritance (pusako) property is in the form of rice field which is an economic source according to Minangkabau's custom, its use is preferred for women. This is because women are weaker than men with broader abilities and freedoms. However, the protection of women's rights as bundo candidates is not fully applicable to the Blanti s community (Orang orang Blanti).

\section{b. As a Tribal Member}

Bundo kanduang as a figure who has a strong position in making decisions in Minangkabau's culture. In Blanti's novel, bundo kanduang should also be a figure to be reckoned with in culture. However, the position of this bundo kanduang is not as it should be. This happens because the role of men as penghulu or uncle (mamak) more powerful than bundo kanduang. It can be seen in the following statement.

.... there is no word he can say. What a great fight between grandmother and her own brother Datuk Tuo. To seize the land of heritage. Grandmother relented to avoid division. Accept what is decided. The land must be divided. The working islanders were divided (Wisran, 2000, p. 41).

Through the statement above it appears that the grandmother as a woman in the people has no power to defend the land of inheritance (pusako). Supposedly as a woman in the family, grandma has the power to defend the land of inheritance (pusako) so as not to be divided and sold. It happened because of the power possessed by Datuk Tuo as the man who should keep the heritage remains the rights of women or bundo kanduang. The same is true of Empon figures, as noted in the following statement :

However, a few years later, the only boy who was expected to defend him, went along like his father.

Selling the land a piece-pieces to a variety of reasons. At first with the reasons forced to make the highway. Then to build a housing complex (Wisran, 2000, p.67).

Through the story of Empon also seen the seizure of rights to women, both by the husband as a person who is outside the family or by his own son. Empon as a woman in her people has no power to defend the land of inheritance (pusako) which should be her right. Thus, through the depiction of Grandma and Empon tokens, it appears that the figure of bundo kanduang as people who are included in determining decisions and having power especially against pusako land was not applicable in Blanti society. It happens because of the helplessness of women. In addition to helplessness, it happens because of compulsion by a certain condition that is done by the men.

\section{The Role and the Position of Women as Bundo Kanduang in the Novel "Negeri Perempuan" by Wisran Hadi a. As Mother}

In carrying out her function as a bundo kanduang, Bundo is usually assisted by her daughter named Reno. Reno works out of town. If Bundo requires Reno, Bundo will tell Reno to go home. That is, Bundo can not work alone in performing the function so that she needs other people who are still one community (kaum). It is as shown in the following statement.

As things get worse, the bundo is always trying to persuade Reno to go home. In addition to help to manage the results of rice fields and fields, it is important to participate in carrying out the parent function in the community, as shoot custom. (Wisran, 2001, p. 17) 
Through the statemen,t it is seen that bundo also fully authorizes Reno in deciding a case. Bundo never regretted or blamed every decision that Reno had made. If Reno has decided a case, that decision is a bundo ' $s$ decision that must also be obeyed as well as obeying bundo's decision. It can be seen in the statement below.

"If you come there must be a problem, right? Well, talk to Reno, I'll go to the hospital to see the wife of Burik giving birth, "said Bundo went with Masam ... (Wisran, 2001, p. 83).

"Which is the issue now, whether Reno is still allowing the event to take place or not. If Reno does not agree practically Bundo also will not agree, "said another (Wisran, 2001, p. 132).

Through the statement it appears that the bundo as a mother gives full confidence to her son. With this trusting attitude, as a mother, bundo tries to teach her child to be independent and to be wise in taking every decision. Not only that, bundo also fully support the decisions that have been taken bundo. Attitude such bundo will make a child confident in making the best decisions.

\section{b. As a Tribal Member}

In the novel "Negeri Perempuan", bundo kanduang figure depicted through the character bundo is a family leader heir to the Kingdom Nagariko. A traditional ceremony will not be attended by uncle (pangulu) if bundo is not presented as in the following statement :

If they do not want to follow the customary rules as uncle (penghulu) wants, it is possible that the inauguration ceremony can fail. All threatening warriors will not be present at the inauguration ceremony of Puri Alam if bundo and her family are not presented as traditional shoots or heirs of kings. Finally the bundo 's family is shown with all its greatness. (Wisran, 2001, p. 5)

Basically the position of bundo kanduang in a community (kaum) aims to guard, protect the treasure of the heritage from extinction. As a true mother, bundo kanduang serves as a leader in the household, guarding the treasures. In addition to creat and maintain the harmony of households, bundo kanduang also duty to create and maintain harmony of the people, kinsman relatives and communities around where she lived. In the novel "Negeri Perempuan" described that bundo is also a person who is warm and care about the state of others regardless of social status and selfless. It can be seen through the following statement.

A few days later bundo discusses this problem with uncle (penghulu). They cannot do anything, even knowing what the humble unfortunate families are going to endure (Wisran, 2001, p. 25).

In everyday life, bundo is a figure who liked by people around her. Bundo can set a good example to be a role model for others. Even a bundo kanduang must be able to tackle all the problems faced by people around the people and district (nagari). She is not only to think of themselves and their families, but also to care about those around them. Bundo's attitude can be seen in the following statement.

.... While Bundo is busy with the Nagariko community. All the problems, ranging from lack of rice to be cooked everyday to the affairs of the son-in-law, married divorce, the child was born and all the affairs of the diladation service with loving care. Bundo is unlikely to avoid because she is the mother, mother to all the inhabitants of Nagariko ... (Wisran, 2001, p. 17)

Bundo acts as the mother in Nagariko society. Bundo takes care of all matters with affection, ranging from the procurement of rice in law affairs, divorce marriage, and so on. Bundo is always busy making the father (bundo 's husband) angry. Father does not want his wife to foster the Nagariko society. However, bundo as the wife persuades father gently. Bundo also persuade Reno to go back more often to take care of the fields and also to carry out the parent function in the community as the customary shoots as in the following statement.

"Whatever you treat you, you remain my son. Do not mix with what has been my decision, "Bundo replies while stroked Rendopati who cried lap. (Wisran, 2001, p. 90)

Based on the statement above, it is seen that bundo has been running her role as a bundo kanduang. Bundo is in addition to attention, has also been taking care of all the needs of her people well, ranging from daily necessities to the activities of traditional ceremonies. Bundo is just as a symbol for the Nagariko community which is a picture of the figure of bundo kandung for Minangkabau's society. Her words and counsel are heard, but they are not used in living anywhere. 
In the novel "Negeri Perempuan", the role of bundo kanduang is very felt. Bundo and Reno as the heirs of the Rumah Gadang in the Nagariko Kingdom always protect member of the people, and maintain dignity, and dignity itself. Furthermore, the two female characters in the novel also keep trying to defend what belongs to her. It is seen when the title in her family is used by Mr. Anjang for personal gain. Mr. Anjang's preliminary title is not the title of his people, but the title given by the grandmothers of the bundo's family. So is Pak Sati. He is not a Nagariko. It may be that they both have no net intentions towards the progress made by the Nagariko community.

\section{CONCLUSION}

Based on the findings and research results on colors local Minangkabau's novel in New Era, it can be concluded that the role and the position of bundo kanduang as women have got a decent place and preferred, but it is only a new symbol. They are destined to fulfill their duties as a woman, both to members of the society (kaum) and to their husbands and to the communities in which they live, they have done so. However, in the novel "Negeri Perempuan" and "Orang Orang Blanti" still find the oppression of the rights of the biological bundo. Their live are still limited to taking care of the household, without being able to decide decisions, including in determining their spouses. They are considered good women if they are willing to comply with all decisions taken by men in their families and husbands.

The oppression of women is done by men, either by the party members such as uncle (penghulu) and son, as well as the husband as a person who is outside the community. In the novel "Tambo", "Warisan", and "Bako" seen that women have more flexibility in determining opinions and decisions to determine the way of life independently. They can determine the way of life and spouse and are not so attached to the Minangkabau's cultural customs rules, even they have dared to reject the rules that they think harming the women without relying on the men of her people and the man of her husband. Even in some of the novels have been found the existence of women who work, it is not limited to taking care of the household, but can be involved in the community.

\section{References}

Atmazaki. (1990). Ilmu sastra: teori dan terapan. Angkasa Raya.

Atmazaki. (2003). "Dinamika jender dalam konteks adat dan agama: suatu interpretasi terhadap novel-novel warna lokal Minangkabau" Dissertation. Universitas Negeri Jakarta.

Esten, M. (1984). Kritik sastra indonesia. Angkasa Raya.

Teuw, A. (1980). Sastra indonesia baru. Ende Flores : Nusa Indah.

Hakimy, I. 2004. The handbook of penghulu, bundo kanduang, and speech of alua pasambahan adat in Minangkabau. Bandung: Remaja Rosdakarya.

Navis, AA. (1999). Yang berjalan sepanjang jalan. Jakarta : Grasindo.

Navis AA. (1984). Alam terkembang jadi guru: Adat dan kebudayaan Minangkabau. Jakarta : Graffiti Press.

Koentjaraningrat, P. (1974). Manusia dan kebudayaan di Indonesia. Jakarta. Djambatan.

Luxemburg, Jan Van, et al. 1989. Introduction to Literature (translated by Dick Hartoko). Jakarta: Gramedia Pustaka Utama.

Semi, MA. (1984). Anatomi sastra. Padang : Sridharma.

Semi, MA. (1990). Metode Penelitian Sastra. Bandung : Angkasa.

Sakai, G. T., \& Putra, R. M. S. (2000). Tambo:(sebuah pertemuan). Grasindo.

Saydam, G. (2004). Kamus lengkap bahasa Minang: Minang-Indonesia, Indonesia-Minang (Vol. 1). Pusat Pengkajian Islam dan Minangkabau.

Yusriwal. (2005). Kieh pasambahan manjampuik marapulai di Minangkabau: Kajian estetika dan semiotika. Padang. Pusat Kajian Islam dan Minangkabau. 